CLINICAL STUDY

\title{
Serum sex steroids measured in middle-aged European and African-Caribbean men by gas chromatography-mass spectrometry
}

Frank Giton ${ }^{1,2, *}$, Jean Fiet ${ }^{2, *}$, Jean-Nicolas Cornu ${ }^{3}$, Olivier Cussenot $^{3,4}$, Alain Bélanger ${ }^{5}$, Saîk Urien ${ }^{6}$, Alejandro Oliva ${ }^{7}$, Pascal Blanchet ${ }^{8,9}$ and Luc Multigner ${ }^{9}$

${ }^{1}$ AP-HP CIB GHU Sud, Hôpital Henri Mondor, Creteil, France, ${ }^{2}$ INSERM U955 EqO7, Faculty of Medicine, Centre de Recherches Chirurgicales, 8 Rue du Général Sarrail, 94010 Creteil cedex, France, ${ }^{3}$ Department of Urology, Tenon Hospital, AP-HP, University Paris VI, Paris, France, ${ }^{4}$ CeRePP, Tenon Hospital, AP-HP, Paris, France, ${ }^{5}$ Laboratory of Molecular Endocrinology and Oncology, Centre de Recherche du Centre Hospitalier Universitaire de Québec (CR-CHUQ) and Faculty of Medicine, Laval University, Quebec City, Quebec, Canada, ${ }^{6}$ Clinical Research Unit, Tarnier Hospital, Paris, France, ${ }^{7}$ Unidad de Andrologia, Hospital Italiano, Rosario, Argentina, ${ }^{8}$ Department of Urology, CHU Pointe-à-Pitre, Guadeloupe, French West Indies and ${ }^{9}$ INSERM U625, Pointe-à-Pitre, Guadeloupe, French West Indies

(Correspondence should be addressed to J Fiet; Email: fiet@univ-paris12.fr)

*(F Giton and J Fiet contributed equally to this work)

\begin{abstract}
Background: Differences in circulating steroid hormone levels have been hypothesized to explain ethnic differences in steroid-related diseases. The aim of this study was to determine the serum levels of a wide panel of steroid hormones, both androgens and estrogens, in healthy middle-aged African-Caribbean and European men.

Design and methods: Serum steroid hormone levels were determined in men participating in a systematic public health study funded by the French National Health Insurance system. Blood was collected in the morning from 304 healthy African-Caribbean and European men aged between 40 and 69 years. Serum steroids were measured by mass spectrometry-gas chromatography, except for DHEAS and sex hormone-binding globulin, which were determined by RIA. Data were analyzed in 10-year age intervals by analysis of covariance, with adjustment for age, body mass index, waist-to-hip ratio, tobacco and alcohol consumption, and season of sampling.

Results: Compared with Europeans, African-Caribbean men presented significantly higher serum levels of measured bioavailable testosterone, 4-androstenedione (4-dione), and estrone (E1) regardless of the age group, of 5-androstenediol (5-diol) in those aged 40-49 and 50-59 years, and of testosterone (TT) and dihydrotestosterone in those aged 40-49 years. In contrast, European men aged 40-69 years showed significantly higher serum levels of DHEA and DHEAS.

Conclusions: Significant differences in serum steroid hormone levels were observed in middle-aged African-Caribbean and European men. Whether such differences could contribute to ethnic differences in disease risk in adult men remains to be investigated. Some steroids, such as bioavailable TT, 4-dione, 5-diol, and E1, deserve particular attention.
\end{abstract}

European Journal of Endocrinology $165917-924$

\section{Introduction}

Ethnic differences in the incidence of cardiovascular disease (1), osteoporosis (2), bone fractures (3), and prostate cancer (4) in men, have been hypothesized to be related to lifelong differences in androgen or estrogen exposure.

Several studies comparing blood androgen and estrogen concentrations in various ethnic groups, particularly between African-American and Caucasian men (5-17), have resulted in conflicting results. Moreover, because of differences in steroid hormone assay methods and/or the broad age range of patients included in the reference studies, it is difficult to achieve a generally consistent analysis of these papers. To overcome these limitations, we focused on two healthy, middle-aged (40-69 years) male populations of African and Caucasian origin. In these two ethnic groups, we examined and compared a wide panel of blood androgens and estrogens at 10-year age intervals. Steroid hormones were measured by gas chromatography-mass spectrometry (GC-MS), a method considered to be the gold standard for steroid hormone assay (18). 


\section{Materials and methods}

\section{Population}

Subjects were recruited between 2005 and 2006 among 40- to 69-year-old men participating in a free yearly systematic health-screening program open to general public funded by the French National Health Insurance system. Each year, a random population sample selected in accordance with the sex and age distribution of the general population is invited to participate in the program. Caribbean subjects of African descent (African-Caribbeans) were recruited in Les Abymes, the biggest city in Guadeloupe (French West Indies), a Caribbean archipelago in which most inhabitants are of African descent (19). European subjects of Caucasian descent (Europeans) were recruited in Tours, the biggest city in the Indre-et-Loire Province (mainland France) (20). Subjects were selected according to the birthplaces of their parents as follows: any Caribbean island the population of which is predominantly of African descent for African-Caribbean subjects and Western Europe for European subjects.

Information was obtained from participants regarding demographic characteristics, anthropometrics (weight, height, waist, and hip measurements), lifestyle (past or current tobacco and alcohol consumption), medical records, and medication use. A blood sample was drawn from each participant between 0800 and $1000 \mathrm{~h}$, after a recommended overnight fast. Inclusion criteria were as follows: body mass index (BMI) $<30$, no history of medical disorder (including cancer), standard biochemical and hematological blood parameters in the normal range, no hormone treatments or drugs known to influence the hypothalamic/pituitary/gonadal and adrenal axes, a normal digital rectal examination, a total plasma prostate-specific antigen concentration lower than the 75th percentile, when plotted against the age group for African-American men without clinical evidence of prostate cancer for subjects of African origin (21), and lower than $1.5 \mathrm{ng} / \mathrm{ml}$ for subjects of European origin.

Five hundred consecutively enlisted men aged 40-69 years of age in each location were invited to participate in the study. The acceptance rate was around $90 \%$ in both cities. After exclusion of men who did not fulfill the inclusion criteria or who had provided a blood sample insufficient to carry out all hormonal assays, 304 African-Caribbeans and 325 Europeans were finally enrolled in the study.

The study was approved by both the Guadeloupe and Tours University Hospital Ethics Committees for studies involving human subjects. Each participant provided written informed consent.

\section{Laboratory procedures}

After clotting, serum was separated and kept at $-30{ }^{\circ} \mathrm{C}$. Samples were blinded and analyzed in a randomized manner. Three control serum samples used, as quality control plus a serum of very low concentrations were included in each run.

DHEA, $\Delta 4$-androstenedione (4-dione), $\Delta 5$-androstenediol (5-diol), testosterone (TT), dihydrotestosterone (DHT), estrone (E1), estradiol $\left(\mathrm{E}_{2}\right)$, and E1 sulfate (E1-S) were assayed simultaneously by MS coupled with GC on $1000 \mu \mathrm{l}$ serum $(20,22,23)$. Briefly, deuterated steroid internal standards (CDN Isotopes, Inc., Point-Claire, Quebec, Canada) were added to all serum samples and extracted with 1-chlorobutane. The organic extracts

Table 1 Analytical control validation and normal serum values for young Caucasians. The data for LLOQ, low, middle, and high QC samples are presented as means of 32 runs (intra- and inter-assay coefficients of variation (\%)).

\begin{tabular}{|c|c|c|c|c|c|c|c|}
\hline $\begin{array}{l}\text { Assay method/ } \\
\text { analytes }\end{array}$ & $\begin{array}{l}\text { TIA/IS } \\
\text { (amu) }\end{array}$ & $\begin{array}{l}\text { Det. range } \\
(\mathrm{nmol} / \mathrm{l})\end{array}$ & $\begin{array}{c}\text { LLOQ } \\
(\mathrm{nmol} / \mathrm{l})\end{array}$ & $\begin{array}{c}\text { Low QC } \\
(\mathrm{nmol} / \mathrm{l})\end{array}$ & $\begin{array}{c}\text { Middle QC } \\
\text { (nmol/l) }\end{array}$ & $\begin{array}{l}\text { High QC } \\
(\mathrm{nmol} / \mathrm{l})\end{array}$ & $\begin{array}{c}\text { Normal Caucasian } \\
\text { values }^{\mathrm{a}}\end{array}$ \\
\hline \multicolumn{8}{|l|}{ GC-MS ${ }^{b}$} \\
\hline DHEA & $482 / 485$ & $0.64-28.09$ & $0.64(5.4-6.1)$ & $2.60(3.5-4.7)$ & $6.90(2.6-2.8)$ & $17.58(1.4-2.0)$ & 25.69 (12.60-43.65) \\
\hline 4-Dione & $461 / 468$ & $0.17-14.14$ & $0.17(6.2-10.8)$ & $1.68(3.7-4.9)$ & $3.53(3.1-4.1)$ & $7.05(2.4-3.8)$ & $4.71(2.59-7.54)$ \\
\hline 5-Diol & $678 / 683^{a}$ & $0.37-13.95$ & $0.37(7.0-11.0)$ & $1.06(4.0-4.4)$ & $2.55(3.7-4.2)$ & $5.10(2.7-3.2)$ & 6.78 (3.58-11.37) \\
\hline TT & $482 / 485$ & $0.17-28.09$ & $0.17(4.8-10.1)$ & $1.66(2.2-3.1)$ & $8.53(2.1-2.5)$ & $20.60(1.0-1.7)$ & $17.72(10.88-26.14)$ \\
\hline $\mathrm{E}_{2}$ & $660 / 664$ & $7.7^{\mathrm{c}}-1487^{\mathrm{c}}$ & $7.7^{\mathrm{C}}(8.9-10.5)$ & $36.0^{c}(3.5-4.1)$ & $176.2^{\mathrm{C}}(2.6-3.0)$ & $728.0^{c}(1.5-1.7)$ & $114.5^{\mathrm{c}}(81.9-151.2)$ \\
\hline E1-S & $464 / 468^{d}$ & $0.13-16.11$ & $0.13(8.7-11.0)$ & $1.34(4.0-4.4)$ & $4.00(3.1-3.4)$ & $7.98(2.8-2.9)$ & $2.55(1.21-4.28)$ \\
\hline DHT & $484 / 487$ & $0.07-13.95$ & $0.07(7.8-9.0)$ & $0.65(3.0-3.1)$ & $1.65(2.0-2.3)$ & $5.13(1.7-1.7)$ & $2.03(1.14-3.16)$ \\
\hline \multicolumn{8}{|c|}{ ASP $(20)+$ GC-MS } \\
\hline BT & & & & $1.01(3.2-3.5)$ & $3.74(4.2-4.3)$ & $8.98(1.4-1.5)$ & $6.93(4.37-10.34)$ \\
\hline \multicolumn{8}{|l|}{ RIA } \\
\hline SHBG & & $6.0-164.0$ & & $16.0(2.0-2.3)$ & $41.9(2.9-3.3)$ & $68.4(1.8-2.3)$ & $27.4(14.3-41.7)$ \\
\hline DHEAS & & $0.23^{\mathrm{e}}-23.05^{\mathrm{e}}$ & & & $1.4^{\mathrm{e}}(2.2-3.5)$ & & $8.07^{\mathrm{e}}(4.28-11.55)$ \\
\hline
\end{tabular}

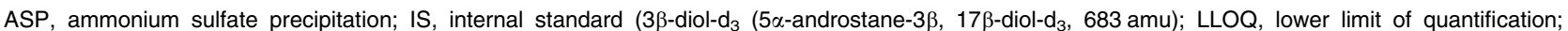
$\mathrm{QC}$, quality control; TIA, target ions analyte; Det., detection.

a 20-39 years ( $n=147$; mean (10th to 90th percentiles)).

${ }^{\mathrm{b}}$ Accuracy for eight steroids measured by GC-MS in human samples: -3.8 to $+3.4 \%(n=6)$.

${ }^{c}$ Means of the $\mathrm{QC}$ serums are expressed in nmol/l except $E_{2}$ and $E 1$ in pmol/l.

${ }^{\mathrm{d}}$ After solvolysis.

${ }^{\mathrm{e}}$ Means of the QC serums are expressed in $\mathrm{nmol} / \mathrm{l}$ except DHEAS in $\mu \mathrm{mol} / \mathrm{l}$. 
were purified on conditioned high-purity silica LC-Si SPE columns (Varian, Les Ulis, France). DHEA, 5-diol, TT, DHT, E1, and $\mathrm{E}_{2}$ were derivatized with pentafluorobenzoyl chloride (103772, Aldrich) and 4-dione with pentafluorobenzylhydroxylamine (P4190, Aldrich). The final extracts were reconstituted in isooctane, and then transferred into conical vials for injection into the GC system $(6890 \mathrm{~N}$, Agilent Technologies, Massy, France), using a 50\% phenylmethylpolysiloxane VF$17 \mathrm{MS}$ capillary column $(20 \mathrm{~m} \times 0.15 \mathrm{~mm}$, internal diameter, $0.15 \mu \mathrm{m}$ film thickness; Varian). An HP5973 (Agilent Technologies) quadrupole mass spectrometer equipped with a chemical ionization

Table 2 Baseline characteristics of the subjects.

\begin{tabular}{|c|c|c|c|}
\hline Characteristics & $\begin{array}{c}\text { African- } \\
\text { Caribbeans }\end{array}$ & Europeans & $\boldsymbol{P}$ \\
\hline \multicolumn{4}{|c|}{ Age (years; mean (s.D.)) } \\
\hline All ages & $57.0(7.7)$ & $53.9(7.9)$ & $<0.0001$ \\
\hline 40 to $<50$ yoa & $46.0(3.0)$ & $44.0(2.9)$ & $<0.0001$ \\
\hline 50 to $<60$ yoa & $55.0(2.7)$ & $54.8(3.0)$ & 0.52 \\
\hline 60 to $<70$ yoa & $64.8(3.0)$ & $62.9(2.3)$ & $<0.0001$ \\
\hline \multicolumn{4}{|c|}{ Body mass index $\left(\mathrm{kg} / \mathrm{m}^{2}\right.$; mean (S.D.)) } \\
\hline All ages & $24.6(2.8)$ & $25.1(2.4)$ & 0.02 \\
\hline 40 to $<50$ yoa & $24.7(2.7)$ & $24.6(2.4)$ & 0.69 \\
\hline 50 to $<60$ yoa & $24.7(3.1)$ & $25.0(2.3)$ & 0.32 \\
\hline 60 to $<70$ yoa & $24.5(2.7)$ & $25.8(2.4)$ & 0.0003 \\
\hline \multicolumn{4}{|c|}{ Waist-to-hip ratio (mean (s.D.)) } \\
\hline All ages & $0.90(0.08)$ & $0.91(0.06)$ & 0.006 \\
\hline 40 to $<50$ yoa & $0.86(0.07)$ & $0.89(0.05)$ & 0.002 \\
\hline 50 to $<60$ yoa & $0.90(0.08)$ & $0.92(0.06)$ & 0.18 \\
\hline 60 to $<70$ yoa & $0.91(0.08)$ & $0.93(0.05)$ & 0.03 \\
\hline \multicolumn{4}{|c|}{ Former or current smokers, $n(\%)$} \\
\hline All ages & $116(38)$ & $159(49)$ & 0.006 \\
\hline 40 to $<50$ yoa & $21(33)$ & $55(55)$ & 0.007 \\
\hline 50 to $<60$ yoa & $52(43)$ & $64(50)$ & 0.22 \\
\hline 60 to $<70$ yoa & $43(36)$ & $40(41)$ & 0.48 \\
\hline \multicolumn{4}{|c|}{ Former or current drinkers, $n(\%)$} \\
\hline All ages & $249(84)$ & $296(91)$ & 0.006 \\
\hline 40 to $<50$ yoa & $48(79)$ & $86(86)$ & 0.23 \\
\hline 50 to $<60$ yoa & $109(90)$ & $117(92)$ & 0.57 \\
\hline 60 to $<70$ yoa & $92(80)$ & $93(95)$ & 0.001 \\
\hline \multicolumn{4}{|c|}{ Season of blood collection, $n(\%)$} \\
\hline \multicolumn{4}{|c|}{ All ages } \\
\hline Spring & $72(24)$ & $34(11)$ & $<0.0001$ \\
\hline Summer & $71(23)$ & $13(4)$ & \\
\hline Autumn & $80(26)$ & $81(25)$ & \\
\hline Winter & 81 (27) & $197(61)$ & \\
\hline \multicolumn{4}{|l|}{40 to $<50$ yoa } \\
\hline Spring & $32(51)$ & $3(3)$ & $<0.0001$ \\
\hline Summer & $7(11)$ & $0(0)$ & \\
\hline Autumn & $1(2)$ & $0(0)$ & \\
\hline Winter & $23(37)$ & $97(97)$ & \\
\hline \multicolumn{4}{|l|}{50 to $<60$ yoa } \\
\hline Spring & $21(17)$ & $5(4)$ & $<0.0001$ \\
\hline Summer & $36(30)$ & $0(0)$ & \\
\hline Autumn & $41(34)$ & $52(41)$ & \\
\hline Winter & $24(30)$ & $70(55)$ & \\
\hline \multicolumn{4}{|l|}{60 to $<70$ yoa } \\
\hline Spring & $19(16)$ & $26(27)$ & 0.11 \\
\hline Summer & 28 (24) & 13 (13) & \\
\hline Autumn & 38 (32) & $29(26)$ & \\
\hline Winter & 34 (29) & 30 (31) & \\
\hline
\end{tabular}

yoa, years of age. source and operating in single ion monitoring mode was used for detection. E1-S was measured as E1 after acid solvolysis (23) (Table 1).

In Table 1 , we report the molecular mass of the derivatized steroids (deuterated and corresponding nondeuterated steroids) assayed by GC-MS. We also report the means and intra- and inter-assay coefficients of variation $(\mathrm{CV})$ of four quality control sera: one with very low concentrations of the assayed steroids to determine the lower limit of quantification and three with increasing concentration levels (low, middle, and high).

Bioavailable testosterone (BT) was measured by addition of purified tritiated TT to the serum samples, incubating and then precipitating the sex hormone-binding globulin (SHBG)-bound TT with saturated ammonium sulfate $(20,24)$. After centrifugation, we deduced the percentage of SHBG-unbound tritiated TT (BT\%), and multiplying by total TT concentration, we obtained the serum BT concentration. DHEAS was measured by a radioimmunological method (IM 0729, Beckman Coulter, Marseille, France). Plasma SHBG levels were measured by a radioimmunological method (Schering RIACT, Gif-surYvette, France). The results of BT, DHEAS, and SHBG quality control are reported in Table 1.

\section{Statistical analysis}

We normalized the distributions by applying a square root for SHBG or a $\log 10$ transformation for hormones. We used the Kolmogorov-Smirnov test to ensure normality. The transformed values were converted back to normal values for presentation of result.

We used the $\chi^{2}$ test for categorized variables and the unpaired $t$-test for continuous variables. Mean blood hormone levels were compared between the ethnic groups by analysis of covariance. The following covariates were considered potentially confounding factors: age (years), BMI $\left(\mathrm{kg} / \mathrm{m}^{2}\right)$, waist-to-hip ratio, alcohol (never vs ever) and tobacco consumption (never vs ever), and season of blood collection. For all subjects and for each 10-year group, covariates that differed $(P<0.1)$ between the two ethnic groups and that were associated $(P<0.1)$ with hormone or protein levels were included in the model. By a backward elimination procedure, covariates associated with $P>0.1$ were removed. Age was maintained in the final model regardless of significance level. All analyses were carried out using the Statview Software package (SAS Institute, Inc., Cary, NC, USA). All tests were two sided, and $P$ values $<0.05$ were considered to be statistically significant.

\section{Results}

Baseline characteristics of African-Caribbean and European men stratified in 10-year intervals are reported in Table 2. Mean concentrations of each steroid 
hormone tested are presented in Table 3 as well as the 10th and 90th percentiles. Adjusted mean concentrations are presented in Table 4 as well as the 95\% CI. After adjustment, the African-Caribbean men showed significantly higher concentrations of some androgens

Table 3 Mean hormone concentrations (back-transformed mean (10th to 90th percentile)) in African-Caribbean and European men of all ages and by 10 -year age interval.

\begin{tabular}{|c|c|c|c|}
\hline Hormones & African-Caribbeans & Europeans & $\boldsymbol{P}$ \\
\hline \multicolumn{4}{|c|}{ Testosterone (nmol/l) } \\
\hline All ages & $18.27(11.37,29.37)$ & $16.82(11.30,24.65)$ & 0.002 \\
\hline 40 to $<50$ yoa & $20.42(12.03,30.20)$ & $17.58(12.03,27.22)$ & 0.007 \\
\hline 50 to $<60$ yoa & $17.65(11.20,26.91)$ & $16.71(11.20,24.55)$ & 0.22 \\
\hline 60 to $<70$ yoa & $17.82(11.20,29.51)$ & $16.30(10.96,23.44)$ & 0.03 \\
\hline \multicolumn{4}{|l|}{ BT (nmol/l) } \\
\hline All ages & $6.38(2.84,7.56)$ & $4.61(4.16,9.99)$ & $<0.0001$ \\
\hline 40 to $<50$ yoa & $7.87(6.00,11.48)$ & $5.55(3.36,8.29)$ & $<0.0001$ \\
\hline 50 to $<60$ yoa & $6.45(4.16,9.99)$ & $4.40(2.88,6.73)$ & $<0.0001$ \\
\hline 60 to $<70$ yoa & $5.65(3.78,8.29)$ & $4.02(2.50,6.14)$ & $<0.0001$ \\
\hline \multicolumn{4}{|l|}{$\mathrm{DHT}(\mathrm{nmol} / \mathrm{l})$} \\
\hline All ages & $1.96(0.96,3.68)$ & $1.79(1.03,2.93)$ & 0.009 \\
\hline 40 to $<50$ yoa & $2.07(1.07,3.75)$ & $1.65(0.86,2.86)$ & 0.002 \\
\hline 50 to $<60$ yoa & $1.89(0.90,3.27)$ & $1.93(1.17,3.00)$ & 0.58 \\
\hline 60 to $<70$ yoa & $2.00(0.96,4.20)$ & $1.72(1.03,2.93)$ & 0.03 \\
\hline \multicolumn{4}{|l|}{ DHEA (nmol/l) } \\
\hline All ages & $9.99(5.06,18.20)$ & $11.48(5.34,24.93)$ & 0.002 \\
\hline 40 to $<50$ yoa & $12.69(6.93,22.36)$ & $16.89(8.11,30.17)$ & 0.0004 \\
\hline 50 to $<60$ yoa & $10.58(5.37,19.07)$ & $10.85(5.62,20.87)$ & 0.74 \\
\hline 60 to $<70$ yoa & $8.22(4.47,15.85)$ & $8.32(3.81,16.19)$ & 0.90 \\
\hline \multicolumn{4}{|l|}{ DHEAS $(\mu \mathrm{mol} / \mathrm{l})$} \\
\hline All ages & $2.89(1.25,5.99)$ & $3.57(1.54,7.37)$ & $<0.0001$ \\
\hline 40 to $<50$ yoa & $3.25(1.58,6.89)$ & $5.19(2.74,9.30)$ & $<0.0001$ \\
\hline 50 to $<60$ yoa & $2.68(1.54,6.29)$ & $3.34(1.85,6.00)$ & 0.27 \\
\hline 60 to $<70$ yoa & $2.52(1.17,5.48)$ & $2.65(1.31,5.23)$ & 0.58 \\
\hline \multicolumn{4}{|l|}{ 4-Dione $(\mathrm{nmol} / \mathrm{l})$} \\
\hline All ages & $4.02(2.44,6.77)$ & $3.32(1.92,5.66)$ & $<0.0001$ \\
\hline 40 to $<50$ yoa & $4.82(3.11,7.65)$ & $4.12(2.37,6.35)$ & 0.007 \\
\hline 50 to $<60$ yoa & $3.95(2.41,6.08)$ & $3.28(1.99,5.52)$ & 0.001 \\
\hline 60 to $<70$ yoa & $3.74(2.30,6.22)$ & $2.65(1.68,2.90)$ & $<0.0001$ \\
\hline \multicolumn{4}{|l|}{ 5-Diol (nmol/l) } \\
\hline All ages & $4.99(2.10,10.40)$ & $4.27(2.27,7.33)$ & 0.0003 \\
\hline 40 to $<50$ yoa & $7.06(3.44,12.78)$ & $4.82(3.06,7.54)$ & $<0.0001$ \\
\hline 50 to $<60$ yoa & $5.30(2.65,10.16)$ & $4.24(2.27,8.06)$ & 0.0007 \\
\hline 60 to $<70$ yoa & $3.82(1.72,8.64)$ & $3.79(1.86,6.40)$ & 0.82 \\
\hline \multicolumn{4}{|l|}{$\mathrm{E}_{2}(\mathrm{pmol} / \mathrm{l})$} \\
\hline All ages & $109.8(72.7,164.8)$ & $105.0(77.8,145.4)$ & 0.07 \\
\hline 40 to $<50$ yoa & $112.1(58.2,139.5)$ & $103.7(65.3,118.8)$ & 0.09 \\
\hline 50 to $<60$ yoa & $106.4(54.3,139.5)$ & $107.3(63.8,130.2)$ & 0.77 \\
\hline 60 to $<70$ yoa & $112.4(58.2,136.4)$ & $103.9(56.8,124.4)$ & 0.05 \\
\hline \multicolumn{4}{|l|}{$\mathrm{E} 1(\mathrm{pmol} / \mathrm{l})$} \\
\hline All ages & $150.2(100.2,235.6)$ & $101.7(58.1,172.0)$ & $<0.0001$ \\
\hline 40 to $<50$ yoa & $136.5(95.0,198.6)$ & $93.1(53.4,140.6)$ & $<0.0001$ \\
\hline 50 to $<60$ yoa & $150.7(97.3,233.3)$ & $106.9(64.2,181.1)$ & $<0.0001$ \\
\hline 60 to $<70$ yoa & $159.2(101.8,250.0)$ & $104.2(58.6,173.0)$ & $<0.0001$ \\
\hline \multicolumn{4}{|l|}{$\mathrm{E} 1-\mathrm{S}(\mathrm{nmol} / \mathrm{l})$} \\
\hline All ages & $1.61(0.75,3.65)$ & $1.64(0.83,3.14)$ & 0.92 \\
\hline 40 to $<50$ yoa & $1.40(0.73,3.28)$ & $1.48(0.75,2.55)$ & 0.55 \\
\hline 50 to $<60$ yoa & $1.69(0.75,3.79)$ & $1.69(0.89,3.22)$ & 0.88 \\
\hline 60 to $<70$ yoa & $1.69(0.62,3.30)$ & $1.72(0.91,3.30)$ & 0.88 \\
\hline \multicolumn{4}{|l|}{ SHBG (nmol/l) } \\
\hline All ages & $34.9(16.7,58.3)$ & $34.2(20.2,52.4)$ & 0.25 \\
\hline 40 to $<50$ yoa & $30.6(14.6,54.4)$ & $29.4(15.9,46.7)$ & 0.68 \\
\hline 50 to $<60$ yoa & $32.0(15.1,54.0)$ & $35.5(20.3,58.8)$ & 0.05 \\
\hline 60 to $<70$ yoa & $40.6(20.1,71.4)$ & $35.1(21.3,58.4)$ & 0.01 \\
\hline
\end{tabular}

yoa, years of age.
(TT, BT, 4-dione, and 5-diol) and of one estrogen (E1), and lower concentrations of the androgen conjugate (DHEAS), compared with the European men. When stratified by age groups in 10-year intervals, higher levels of BT, 4-dione, and E1 were significant, regardless of the age group. However, after stratification, in the African-Caribbeans, significant higher TT and DHT and significantly lower DHEA and DHEAS were observed only in the 40- to 49-year interval and higher 5-diol levels in the 40-49 and 50-59 year intervals. Slightly higher $\mathrm{E}_{2}$ levels, but no significantly higher adjusted $\mathrm{E}_{2}$ levels, were found in the African-Caribbeans. No differences were observed between the ethnic groups for SHBG and E1S, regardless of the age group.

\section{Discussion}

In this article, we report the blood levels of major steroid hormones involved in the steroid metabolic pathway, mostly measured by GC-MS, in two populations of non-obese, healthy, middle-aged men of two ethnic backgrounds: African-Caribbean and European. We compared these hormone levels both overall and in 10-year age intervals. In the broad 40- to 69-year age interval, we found TT levels to be higher in AfricanCaribbeans than in Europeans. Similarly, higher TT levels were reported in five of the 12 studies comparing African-Americans and white Americans (Table 5). When we analyzed the data in 10-year age intervals, the TT level remained statistically higher in African-Caribbean only in the 40- to 49-year age interval. As the results comparing African-Caribbeans and Europeans were age dependent, it could be important to extend this comparison to groups of these populations aged between 20 and 40 years. Indeed, significantly higher TT levels were reported in rather narrow age intervals of populations of young African-Americans than in young white American students 25-36 and 18-24 years old (Table 5).

As was the case for TT, we also found higher DHT in African-Caribbeans than in Europeans in the age range of 40-49 years, but not in the other age ranges or in the wide 40- to 69-year interval. Of the six studies known to report DHT in African-Americans and in white Americans, three reported significantly higher DHT in African-Americans (Table 5) in broad age intervals. Moreover, all DHT assays were carried out using lowspecificity immunoassays, except for the last published study (17), which used GC-MS.

We did not find SHBG concentrations to be significantly different between African-Caribbeans and Europeans regardless of the age range, which is in accordance with previous studies comparing AfricanAmericans and white Americans (7-9, 11-14, 16).

A assayed BT, which has been described as an index of androgenicity (25), was found to be significantly higher in African-Caribbean than in European in the broad 40- to 69-year age interval and in each 10-year range. 
Table 4 Adjusted mean concentrations (back-tranformed mean $(95 \% \mathrm{Cl}))$ of steroid hormones in men of African-Caribbean and European origin at all ages and by 10 -year age interval.

\begin{tabular}{|c|c|c|c|}
\hline Hormones & African-Caribbeans & Europeans & Adjusted $P^{\mathrm{a}}$ \\
\hline \multicolumn{4}{|c|}{ Testosterone (nmol/l) } \\
\hline All ages & $18.27(17.61,19.00)$ & $16.85(16.23,17.48)$ & $0.003^{\mathrm{B}}$ \\
\hline 40 to $<50$ yoa & $20.42(18.76,22.23)$ & $17.55(16.40,18.76)$ & $0.008^{\mathrm{A}}$ \\
\hline 50 to $<60$ yoa & $17.65(16.57,18.76)$ & $16.68(15.71,17.72)$ & $0.20^{\mathrm{A}}$ \\
\hline 60 to $<70$ yoa & $17.58(16.50,18.69)$ & $16.75(15.64,17.93)$ & $0.33^{\mathrm{B}}$ \\
\hline \multicolumn{4}{|l|}{ BT (nmol/l) } \\
\hline All ages & $6.59(6.31,6.83)$ & $4.47(4.33,4.65)$ & $<0.0001^{\mathrm{A}}$ \\
\hline 40 to $<50$ yoa & $8.01(7.35,8.74)$ & $5.48(5.13,5.86)$ & $<0.0001^{\mathrm{A}}$ \\
\hline 50 to $<60$ yoa & $6.45(6.07,6.87)$ & $4.40(4.16,4.68)$ & $<0.0001^{\mathrm{C}}$ \\
\hline 60 to $<70$ yoa & $5.76(5.41,6.14)$ & 3.99 (3.71, 4.26) & $<0.0001^{\mathrm{A}}$ \\
\hline \multicolumn{4}{|l|}{ DHT (nmol/l) } \\
\hline All ages & $1.93(1.83,2.03)$ & $1.83(1.72,1.89)$ & $0.14^{\mathrm{D}}$ \\
\hline 40 to $<50$ yoa & $2.03(1.79,2.27)$ & $1.65(1.52,1.83)$ & $0.01^{\mathrm{E}}$ \\
\hline 50 to $<60$ yoa & $1.86(1.72,2.03)$ & $1.93(1.79,2.10)$ & $0.44^{\mathrm{A}}$ \\
\hline 60 to $<70$ yoa & $1.93(1.76,2.13)$ & $1.83(1.62,2.03)$ & $0.38^{\mathrm{B}}$ \\
\hline \multicolumn{4}{|l|}{ DHEA (nmol/l) } \\
\hline All ages & $10.51(9.92,11.13)$ & $10.96(10.37,11.58)$ & $0.29^{A}$ \\
\hline 40 to $<50$ yoa & $13.25(11.69,15.01)$ & $16.50(14.98,18.20)$ & $0.01^{\mathrm{C}}$ \\
\hline 50 to $<60$ yoa & $10.68(9.74,11.69)$ & $10.82(9.88,7.28)$ & $0.84^{\mathrm{A}}$ \\
\hline 60 to $<70$ yoa & $8.39(7.63,9.26)$ & $8.11(7.32,9.05)$ & $0.68^{F}$ \\
\hline \multicolumn{4}{|l|}{ DHEAS $(\mu \mathrm{mol} / \mathrm{l})$} \\
\hline All ages & $3.02(2.83,3.21)$ & $3.43(3.23,3.64)$ & $0.004^{C}$ \\
\hline 40 to $<50$ yoa & $3.32(2.90,3.80)$ & $5.11(4.59,5.68)$ & $<0.0001^{\mathrm{A}}$ \\
\hline 50 to $<60$ yoa & $3.12(2.85,3.41)$ & $3.33(3.04,3.63)$ & $0.33^{A}$ \\
\hline 60 to $<70$ yoa & $2.62(2.36,2.92)$ & $2.53(2.25,2.85)$ & $0.67^{\mathrm{A}}$ \\
\hline \multicolumn{4}{|l|}{ 4-Dione (nmol/l) } \\
\hline All ages & $4.12(3.95,4.29)$ & $3.25(3.11,3.35)$ & $<0.0001^{\mathrm{B}}$ \\
\hline 40 to $<50$ yoa & $4.85(4.43,5.34)$ & $4.09(3.81,4.40)$ & $0.006^{\mathrm{A}}$ \\
\hline 50 to $<60$ yoa & $3.95(3.70,4.22)$ & $3.28(3.07,3.49)$ & $<0.0001^{\mathrm{A}}$ \\
\hline 60 to $<70$ yoa & $3.74(3.49,4.02)$ & $2.62(2.41,2.83)$ & $<0.0001^{\mathrm{A}}$ \\
\hline \multicolumn{4}{|l|}{ 5-Diol (nmol/l) } \\
\hline All ages & $5.17(4.86,5.48)$ & $3.55(3.89,4.37)$ & $<0.0001^{\mathrm{A}}$ \\
\hline 40 to $<50$ yoa & $7.13(6.40,7.95)$ & $4.79(4.41,5.23)$ & $<0.0001^{\mathrm{A}}$ \\
\hline 50 to $<60$ yoa & $3.89(3.65,4.17)$ & $3.24(3.03,3.44)$ & $0.0004^{A}$ \\
\hline 60 to $<70$ yoa & $3.99(3.62,4.44)$ & $3.65(3.24,4.10)$ & $0.26^{A}$ \\
\hline \multicolumn{4}{|l|}{$\mathrm{E}_{2}(\mathrm{pmol} / \mathrm{l})$} \\
\hline All ages & $109.6(106.1,113.3)$ & $105.2(102.0,108.6)$ & $0.08^{A}$ \\
\hline 40 to $<50$ yoa & $110.8(103.4,118.8)$ & $104.2(98.7,110.1)$ & $0.18^{A}$ \\
\hline 50 to $<60$ yoa & $106.4(101.0,112.4)$ & $107.2(101.9,112.8)$ & $0.83^{A}$ \\
\hline 60 to $<70$ yoa & $111.8(105.9,118.0)$ & $104.6(98.5,111.0)$ & $0.11^{\mathrm{A}}$ \\
\hline \multicolumn{4}{|l|}{$\mathrm{E} 1(\mathrm{pmol} / \mathrm{l})$} \\
\hline All ages & $148.8(142.3,155.6)$ & $102.7(98.3,107.2)$ & $<0.0001^{\mathrm{A}}$ \\
\hline 40 to $<50$ yoa & $139.7(126.4,154.5)$ & $91.7(84.8,99.2)$ & $<0.0001^{\mathrm{C}}$ \\
\hline 50 to $<60$ yoa & $150.6(140.4,161.7)$ & $107.1(99.9,114.7)$ & $<0.0001^{\mathrm{A}}$ \\
\hline 60 to $<70$ yoa & $157.0(145.8,169.4)$ & $104.8(96.6,113.8)$ & $<0.0001^{\mathrm{A}}$ \\
\hline \multicolumn{4}{|l|}{ E1-S (nmol/l) } \\
\hline All ages & $1.64(1.53,1.75)$ & $1.61(1.53,1.72)$ & $0.92^{\mathrm{G}}$ \\
\hline 40 to $<50$ yoa & $1.40(1.21,1.61)$ & $1.45(1.29,1.64)$ & $0.71^{\mathrm{A}}$ \\
\hline 50 to $<60$ yoa & $1.69(1.53,1.85)$ & $1.69(1.53,1.88)$ & $0.89^{A}$ \\
\hline 60 to $<70$ yoa & $1.72(1.56,1.93)$ & $1.69(1.50,1.91)$ & $0.83^{\mathrm{B}}$ \\
\hline \multicolumn{4}{|l|}{ SHBG (nmol/l) } \\
\hline All ages & $33.5(31.9,37.5)$ & $34.8(33.2,36.4)$ & $0.26^{G}$ \\
\hline 40 to $<50$ yoa & $30.2(26.7,34.0)$ & $29.5(26.8,32.4)$ & $0.76^{A}$ \\
\hline 50 to $<60$ yoa & $31.8(29.4,34.3)$ & $35.6(33.1,38.2)$ & $0.11^{\mathrm{C}}$ \\
\hline 60 to $<70$ yoa & $38.6(35.7,41.4)$ & $37.7(34.6,41.0)$ & $0.72^{\mathrm{B}}$ \\
\hline
\end{tabular}

yoa, years of age.

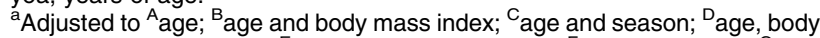
mass index, and alcohol; ${ }^{\mathrm{E}}$ age and waist to hip ratio; ${ }^{\mathrm{F}}$ age and alcohol, ${ }^{\mathrm{G}}$ age, body mass index, and waist-to-hip ratio.
In previous reports, the serum BT level was not different between African-Americans and white Americans (Table 5). The significantly higher assayed BT in African-Caribbeans is consistent with the higher 5-diol levels we found in them. 5-diol has an SHBG association constant similar to that of TT (26) and contributes to the displacement of plasma TT from binding to SHBG (20), consequently to the increase in SHBG-unbound TT and BT in African-Caribbeans.

We found higher 4-dione and 5-diol levels in AfricanCaribbean men compared with Europeans. Such differences were significant in each 10-year range for 4-dione, and in the 40-49 and 50-59 age intervals for 5-diol.

The 5-diol steroid, whose plasma level represents onethird of TT, deserves more study, considering its action on the estrogen receptor and on SHBG, thereby facilitating TT release and increasing androgen action. Indeed, 5-diol has a direct androgenic action, as reported (27), since it can activate the androgen receptor without being metabolized into TT, and has an indirect androgenic effect, since it increases SHBGunbound TT and BT (20).

Contrary to other androgens, we found DHEAS to be significantly lower in the overall population of AfricanCaribbeans than in Europeans, as previously reported in three studies (Table 5) as well as in the 40- to 49-year age interval in our study. In our older AfricanCaribbeans (50-59 and 60-69 year age intervals), this difference became non-significant, though DHEAS decreased more steeply with age in the Europeans. We also found DHEA to be lower in African-Caribbeans in the 40- to 49-year age interval.

We found a slight but non-significantly higher $\mathrm{E}_{2}$ level in African-Caribbeans than in Europeans. Previous studies have led to conflicting conclusions, some showing no significant difference, others reporting higher levels in African-Americans compared with white Americans (Table 5).

An interesting finding is the significantly higher E1 level in African-Caribbeans compared with Europeans. Mean serum E1 levels were 150\% higher in AfricanCaribbeans compared with Europeans regardless of the age interval investigated. These same higher E1 levels in middle-aged men were also reported in younger and older men of African descent (Table 5). Thus, E1 levels appeared to be constantly higher throughout adulthood in men of African descent compared with Caucasians. These higher E1 levels could be related to the significantly higher levels of the 4-dione precursor (28) that we observed in our African-Caribbean population regardless of the age range investigated.

Compared with previous studies (Table 5), ours has several strengths. We simultaneously measured a large number of androgens and estrogens. Except for DHEAS, we used GC-MS for our steroid hormone assays. This sensitive and specific method is currently considered the most accurate for measuring steroid hormones (18). We excluded obese subjects and those with acute or 
Table 5 Mean blood steroid hormone values and methodology assays used in previous studies comparing African-American and Caucasian men.

\begin{tabular}{|c|c|c|c|c|c|c|c|c|c|}
\hline References/ethnicity & $n$ & $\begin{array}{l}\text { Age } \\
\text { ranges }\end{array}$ & $\begin{array}{l}\text { TT } \\
(\mathrm{nmol} / \mathrm{l})\end{array}$ & $\begin{array}{l}\text { BT } \\
(\mathrm{nmol} / \mathrm{l})\end{array}$ & $\begin{array}{l}\text { DHT } \\
(\mathrm{nmol} / \mathrm{l})\end{array}$ & $\begin{array}{l}\text { DHEA } \\
(\mu \mathrm{mol} / \mathrm{l})\end{array}$ & $\begin{array}{l}\text { DHEAS } \\
(\mathrm{nmol} / \mathrm{l})\end{array}$ & $\begin{array}{l}\mathbf{E}_{2} \\
(\mathrm{pmol} / \mathrm{l})\end{array}$ & $\begin{array}{l}\text { E1 } \\
\text { (pmol/l) }\end{array}$ \\
\hline Ross et al. (5) & & Students & RIA & & & & & RIA & RIA \\
\hline African & 50 & & 22.9 & & & & & 77 & 135.4 \\
\hline Caucasian & 50 & & $19.1^{*}$ & & & & & 71.2 & $116.6^{\star}$ \\
\hline Ellys \& Nyborg (6) & & $30-50$ & & & & & & & \\
\hline African & 525 & & 2.8 & & & & & & \\
\hline Caucasian & 3654 & & $22.1^{*}$ & & & & & & \\
\hline Wu et al. (7) & & $>60$ & RIA & ASD & RIA & & & & \\
\hline African & 315 & & 17.2 & 5.48 & 1.68 & & & & \\
\hline Caucasian & 411 & & 16.3 & 5.3 & $1.54^{*}$ & & & & \\
\hline Ettinger et al. (8) & & $25-36$ & IM & CAL & & IM & & & \\
\hline African & 109 & & 20.6 & 11.1 & & 5.14 & & & \\
\hline Caucasian & 114 & & $19.1^{*}$ & 10.3 & & $5.68^{\star}$ & & & \\
\hline Platz et al. (9) & & $47-78$ & RIA & & RIA & & & RIA & \\
\hline African & 43 & & 15.9 & & 1.24 & & & 80.4 & \\
\hline Caucasian & 55 & & 16.3 & & 1.24 & & & 74.1 & \\
\hline Asbell et al. (10) & & $>55$ & RIA & & RIA & & & & \\
\hline African & 12 & & 11.4 & & 1.13 & & & & \\
\hline Caucasian & 26 & & $14.2^{*}$ & & $1.48^{*}$ & & & & \\
\hline Winter et al. (11) & & $18-24$ & RIA & & & & & $\mathrm{RIA}$ & \\
\hline African & 23 & & 23.3 & & & & & 172.4 & \\
\hline Caucasian & 23 & & $18.6^{*}$ & & & & & 157.8 & \\
\hline Ukkola et al. (12) & & $17-65$ & RIA & & RIA & RIA & RIA & RIA & \\
\hline African & 93 & & 14.9 & & 2.89 & 5.79 & 13.88 & 78.9 & \\
\hline Caucasian & 202 & & 14.5 & & $2.47^{\star}$ & 6.46 & 15.9 & 66.4 & \\
\hline Gapstur et al. (13) & & $24-41$ & RIA & & & & & & \\
\hline African & 483 & & 20.1 & & & & & & \\
\hline Caucasian & 695 & & 19.7 & & & & & & \\
\hline Tsai et al. (14) & & $20-55$ & RIA & CAL & & & & RIA & \\
\hline African & 238 & & 24 & 14.9 & & & & 179.8 & \\
\hline Caucasian & 412 & & $21.2^{*}$ & 13.3 & & & & $154.1^{*}$ & \\
\hline Litman et al. (15) & & $30-79$ & ECL & CAL & $\mathrm{RIA}$ & $\mathrm{ECL}$ & & & \\
\hline African & 531 & & 15.7 & 7.5 & 1.65 & 5.35 & & & \\
\hline Caucasian & 702 & & 15 & 7.3 & 1.51 & $5.67^{\star}$ & & & \\
\hline Rohrmann et al. (16) & & $45-69$ & ECL & & & & & $\mathrm{ECL}$ & \\
\hline African & 103 & & 19.5 & & & & & 138.7 & \\
\hline Caucasian & 201 & & 17.3 & & & & & $126.2^{*}$ & \\
\hline Orwoll et al. (17) & & $>65$ & & & GC-MS & & & GC-MS & GC-MS \\
\hline African & 221 & & & & 1.58 & & & 85.5 & 149.1 \\
\hline Caucasian & 427 & & & & $1.30^{\star}$ & & & $73.7^{\star}$ & $118.6^{\star}$ \\
\hline
\end{tabular}

CAL, calculated; ASD, assayed; IM, immunoassay without further precision; GC-MS, gas chromatography-mass spectrometry. ${ }^{\star}$ Significantly different between ethnic groups $(P<0.05)$.

${ }^{\text {a } R o h r m a n n ~ e t ~ a l . ~(16) ~ a l s o ~ r e p o r t e d ~ d a t a ~ f r o m ~} 20$ to 44 years old and 70 years and older.

chronic pathological conditions suspected to be associated with changes in serum steroid hormone levels. The time of blood sampling was carefully controlled to avoid differences related to diurnal variations, and statistical analysis took into account potential confounding factors. Moreover, we investigated our population in narrow 10-year age intervals. This enabled us to discriminate age-dependent progressive variations in serum hormone levels at $\sim 50$ years of age that result from both physiological and physical changes related to aging (29). Nevertheless, we should recognize several limits: the two populations we studied come from different geographical areas, one in the tropical Caribbean and the other in the temperate Western Europe. Therefore, the influence of certain environmental factors known to influence serum steroid levels, such as diet and physical activity, cannot be excluded.
Most of the reported previous studies considered broader age ranges, which are less discriminating. Although the season of blood collection was taken into account as a confounding factor for statistical analysis, residual confounding due to differences in accumulated sunlight exposure time between the two climates cannot be excluded. Finally, the sample sizes in our study do not reveal significant mean differences between ethnic groups $<5-15 \%$, considering the standard deviation of hormone distribution in our population study (data not shown).

Circulating steroid hormone level differences between ethnic groups may be explained by different levels of transcription or allele frequency of polymorphism of steroid hormone-related genes (30). Differences in serum steroid hormone levels have been hypothesized to explain ethnic differences in the risk of some steroid 
hormone-related diseases. For instance, men of African descent are known to present a higher incidence of prostate cancer (4) and a lower prevalence of vertebral fractures compared with Caucasians (3). In addition, polymorphism (repetitions and SNPs) in relevant hormone-related genes has been associated with prostate cancer risk (31-34).

In conclusion, we have shown significantly different serum steroid hormone levels in African-Caribbeans and in Europeans, particularly higher E1, delta-4-dione, and BT in African-Caribbeans. What seems important for further study would be to include the widest possible variety of androgen and estrogen assays and to use irrefutable assay methods, such as GC-MS or LCMS/MS. Moreover, since differences in circulating hormone levels between ethnic groups depend on age, it would be interesting to investigate in which periods of life differences in hormone levels could be etiologically relevant for specific morbid conditions.

\section{Declaration of interest}

The authors declare that there is no conflict of interest that could be perceived as prejudicing the impartiality of the research reported.

\section{Funding}

Supported by the French National Health Directorate.

\section{Acknowledgements}

We thank Dr Noah Hardy for editing the manuscript and René Bérubé for expert technical assistance.

\section{References}

1 Jolly S, Vittinghoff E, Chattopadhyay A \& Bibbins-Domingo K. Higher cardiovascular disease prevalence and mortality among younger blacks compared to whites. American Journal of Medicine 2010123 811-818. (doi:10.1016/j.amimed.2010.04.020)

2 Araujo AB, Travison TG, Harris SS, Holick MF, Turner AK \& McKinlay JB. Race/ethnic differences in bone mineral density in men. Osteoporosis International 200718 943-953. (doi:10.1007/ s00198-006-0321-9)

3 Tracy JK, Meyer WA, Grigoryan M, Fan B, Flores RH, Genant HK, Resnik C \& Hochberg MC. Racial differences in the prevalence of vertebral fractures in older men: the Baltimore Men's Osteoporosis Study. Osteoporosis International 200617 99-104. (doi:10.1007/ s00198-005-1919-z)

4 Hsing AW, Tsao L \& Devesa SS. International trends and patterns of prostate cancer incidence and mortality. International Journal of Cancer 200085 60-67. (doi:10.1002/(SICI)1097-0215 (20000101)85:1 <60::AID-IJC11 > 3.0.CO;2-B)

5 Ross R, Bernstein L, Judd H, Hanisch R, Pike M \& Henderson B. Serum testosterone levels in healthy young black and white men. Journal of the National Cancer Institute 198676 45-48.

6 Ellis L \& Nyborg H. Racial/ethnic variations in male testosterone levels: a probable contributor to group differences in health. Steroids 199257 72-75. (doi:10.1016/0039-128X(92)90032-5)

$7 \mathrm{Wu}$ AH, Whittemore AS, Kolonel LN, John EM, Gallagher RP, West DW, Hankin J, Teh CZ, Dreon DM \& Paffenbarger RS. Serum androgens and sex hormone-binding globulins in relation to lifestyle factors in older African-American, white, and Asian men in the United States and Canada. Cancer Epidemiology, Biomarkers \& Prevention 19954 735-741.

8 Ettinger B, Sidney S, Cummings SR, Libanati C, Bikle DD, Tekawa IS, Tolan K \& Steiger P. Racial differences in bone density between young adult black and white subjects persist after adjustment for anthropometric, lifestyle, and biochemical differences. Journal of Clinical Endocrinology and Metabolism 1997 82 429-434. (doi:10.1210/jc.82.2.429)

9 Platz EA, Rimm EB, Willett WC, Kantoff PW \& Giovannucci E. Racial variation in prostate cancer incidence and in hormonal system markers among male health professionals. Journal of the National Cancer Institute 200092 2009-2017. (doi:10.1093/jnci/ 92.24.2009)

10 Asbell SO, Rajmane KC, Montesano AT, Zeitzer KL, Asbell MD \& Vijayakumar S. Prostate-specific antigen and androgens in AfricanAmerican and white normal subjects and prostate cancer patients. Journal of the National Medical Association 200092 445-449.

11 Winters SJ, Brufsky A, Weissfeld J, Trump DL, Dyky MA \& Hadeed V. Testosterone, sex hormone-binding globulin, and body composition in young adult African American and Caucasian men. Metabolism 200150 1242-1247. (doi:10.1053/meta.2001.26714)

12 Ukkola O, Gagnon J, Rankinen T, Thompson PA, Hong Y, Leon AS, Rao DC, Skinner JS, Wilmore JH \& Bouchard C. Age, body mass index, race and other determinants of steroid hormone variability: the Heritage Family Study. European Journal of Endocrinology 2001 145 1-9. (doi:10.1530/eje.0.1450001)

13 Gapstur SM, Gann PH, Kopp P, Colangelo L, Longcope C \& Liu K. Serum androgen concentrations in young men: a longitudinal analysis of associations with age, obesity, and race. The CARDIA male hormone study. Cancer Epidemiology, Biomarkers \& Prevention 200211 1041-1047.

14 Tsai CJ, Cohn BA, Cirillo PM, Feldman D, Stanczyk FZ \& Whittemore AS. Sex steroid hormones in young manhood and the risk of subsequent prostate cancer: a longitudinal study in AfricanAmericans and Caucasians (United States). Cancer Causes \& Control 200617 1237-1244. (doi:10.1007/s10552-006-0052-4)

15 Litman HJ, Bhasin S, Link CL, Araujo AB \& McKinlay JB. Serum androgen levels in black, Hispanic, and white men. Journal of Clinical Endocrinology and Metabolism 200691 4326-4334. (doi:10.1210/jc.2006-0037)

16 Rohrmann S, Nelson WG, Rifai N, Brown TR, Dobs A, Kanarek N, Yager JD \& Platz EA. Serum estrogen, but not testosterone, levels differ between black and white men in a nationally representative sample of Americans. Journal of Clinical Endocrinology and Metabolism 200792 2519-2525. (doi:10.1210/jc.2007-0028)

17 Orwoll ES, Nielson CM, Labrie F, Barrett-Connor E, Cauley JA, Cummings SR, Ensrud K, Karlsson M, Lau E, Leung PC, Lunggren O, Mellström D, Patrick AL, Stefanick ML, Nakamura K, Yoshimura N, Zmuda J, Vandenput L \& Ohlsson C. Osteoporotic Fractures in Men (MrOS) Research Group. Evidence for geographical and racial variation in serum sex steroid levels in older men. Journal of Clinical Endocrinology and Metabolism 2010 95 151-160. (doi:10.1210/jc.2009-2435)

18 Rosner W, Auchus RJ, Azziz R, Sluss PM \& Raff H. Position statement: utility, limitations, and pitfalls in measuring testosterone: an Endocrine Society position statement. Journal of Clinical Endocrinology and Metabolism 200792 405-413. (doi:10.1210/ jc.2006-1864)

19 Multigner L, Ndong JR, Giusti A, Romana M, Delacroix-Maillard H, Cordier S, Jégou B, Thome JP \& Blanchet P. Chlordecone exposure and risk of prostate cancer. Journal of Clinical Oncology 2010 28 3457-3462. (doi:10.1200/JCO.2009.27.2153)

20 Giton F, Urien S, Born C, Tichet J, Guéchot J, Callebert J, Bronsard F, Raynaud JP \& Fiet J. Determination of bioavailable testosterone (non sex hormone binding globulin (SHBG)-bound testosterone) in a population of healthy French men: influence of androstenediol on testosterone binding to SHBG. Clinical Chemistry 200753 2160-2168. (doi:10.1373/clinchem.2007.087312) 
21 Morgan TO, Jacobsen SJ, McCarthy WF, Jacobson DJ, McLeod DG \& Moul JW. Age-specific reference ranges for prostate-specific antigen in black men. New England Journal of Medicine 1996 335 304-310. (doi:10.1056/NEJM199608013350502)

22 Labrie F, Bélanger A, Bélanger P, Bérubé R, Martel C, Cusan L, Gomez J, Candas B, Castiel I, Chaussade V, Deloche C \& Leclaire J. Androgen glucuronides, instead of testosterone, as the new markers of androgenic activity in women. Journal of Steroid Biochemistry and Molecular Biology 200699 182-188. (doi:10. 1016/j.jsbmb.2006.02.004)

23 Giton F, Caron P, Bérubé R, Bélanger A, Barbier O \& Fiet J. Plasma estrone sulfate assay in men: comparison of radioimmunoassay, mass spectrometry coupled to gas chromatography (GC-MS), and liquid chromatography-tandem mass spectrometry (LC-MS/MS). Clinica Chimica Acta 2010411 1208-1213. (doi:10.1016/j.cca. 2010.04.022)

24 Manni A, Pardridge WM, Cefalu W, Nisula BC, Bardin CW, Santner SJ \& Santen RJ. Bioavailability of albumin-bound testosterone. Journal of Clinical Endocrinology and Metabolism 198561 705-710. (doi:10.1210/jcem-61-4-705)

25 Morley JE, Patrick P \& Perry HM III. Evaluation of assays available to measure free testosterone. Metabolism $2002 \mathbf{5 1} 554-559$. (doi:10.1053/meta.2002.31975)

26 Dunn JF, Nisula BC \& Rodbard D. Transport of steroid hormones: binding of 21 endogenous steroids to both testosterone-binding globulin and corticosteroid-binding globulin in human plasma. Journal of Clinical Endocrinology and Metabolism 198153 58-68. (doi:10.1210/jcem-53-1-58)

27 Miyamoto H, Yeh S, Lardy H, Messing E \& Chang C. $\Delta 5$-Androstenediol is a natural hormone with androgenic activity in human prostate cancer cells. PNAS 199895 11083-11088. (doi:10.1073/pnas.95.19.11083)

28 Longcope C, Kato T \& Horton R. Conversion of blood androgens to estrogens in normal adult men and women. Journal of Clinical Investigation 196948 2191-2201. (doi:10.1172/JCI106185)
29 Hsing AW. Hormones and prostate cancer: what's next? Epidemiologic Reviews 200123 42-58.

30 Eriksson AL, Lorentzon M, Vandenput L, Labrie F, Lindersson M, Syvänen AC, Orwoll ES, Cummings SR, Zmuda JM, Ljunggren O, Karlsson MK, Mellström D \& Ohlsson C. Genetic variations in sex steroid-related genes as predictors of serum estrogen levels in men. Journal of Clinical Endocrinology and Metabolism $2009 \mathbf{9 4}$ 1033-1041. (doi:10.1210/jc.2008-1283)

31 Cussenot O, Azzouzi AR, Nicolaiew N, Fromont G, Mangin P, Cormier L, Fournier G, Valeri A, Larre S, Thibault F, Giordanella JP, Pouchard M, Zheng Y, Hamdy FC, Cox A \& Cancel-Tassin G. Combination of polymorphisms from genes related to estrogen metabolism and risk of prostate cancers: the hidden face of estrogens. Journal of Clinical Oncology 200725 3596-3602. (doi:10.1200/JCO.2007.11.0908)

32 Beuten J, Gelfond JA, Franke JL, Weldon KS, Crandall AC, JohnsonPais TL, Thompson IM \& Leach RJ. Single and multigenic analysis of the association between variants in 12 steroid hormone metabolism genes and risk of prostate cancer. Cancer Epidemiology. Biomarkers \& Prevention 200918 1869-1880. (doi:10.1158/ 1055-9965.EPI-09-0076)

33 Ntais C, Polycarpou A \& Tsatsoulis A. Molecular epidemiology of prostate cancer: androgens and polymorphisms in androgenrelated genes. European Journal of Endocrinology 2003149 469-477. (doi:10.1530/eje.0.1490469)

34 Salam MT, Ursin G, Skinner EC, Dessissa T \& Reichardt JK. Associations between polymorphisms in the steroid 5-alpha reductase type II (SRD5A2) gene and benign prostatic hyperplasia and prostate cancer. Urologic Oncology 200523 246-253.

Received 21 June 2011

Revised version received 27 August 2011

Accepted 21 September 2011 